\title{
Den vakre Kiwa hirsuta - skalldyrenes dronning
}

Det er et privilegium å få leve sammen med alle de andre livsformer på jorden. Vi har nærmest ufattelig mange og fascinerende medskapninger. Virkelig godt kjenner vi bare noen få. Menneskelig virketrang tar uheldigvis livet av stadig flere, samtidig som nye arter oppdages hver dag.

Medisinfaget er en del av biologien, læren om livet. De fleste av de legemidler vi bruker skriver seg fra den levende natur, ofte planter, og de kunnskaper vi baserer vår virksomhet på, skyldes for en stor del studier av dyr. For eksempel ble detaljene om hvordan nerveimpulser oppstår oppdaget ved studier av nevroner hos blekksprut. Vi kan ikke leve uten bakterier, samtidig som noen få av dem kan ta livet av oss hvis vi ikke blir kvitt dem ved hjelp av substanser fra sopp. Vår ernæring kommer i sin helhet fra naturen. Vi har spesifikke reseptorer for opiater, substanser fra planter. Molekyler fra pufferfisk blokkerer menneskecellers natriumkanaler. Det er mange vitnesbyrd om at våre medskapninger også er våre slektninger, slik som Darwin hevdet.

Halvparten av jordens overflate er dekket av vann med en dybde på $2 \mathrm{~km}$ eller mer. De siste årene er det oppdaget at selv på de største havdyp finnes det liv. Mange av disse artene er annerledes enn de vi kjenner fra før, både anatomisk og biokjemisk. Det har flere ganger vært nødvendig å opprette egne phylae for å innlemme disse forunderlige dyr i familiealbumet.

Det bildet som presenteres her, viser et $15 \mathrm{~cm}$ langt dyr som er blitt kalt både krabbe og hummer, men som genetisk ikke passer til noen av disse forslagene. Det er den eneste art i en ny familie, Kiwaidea (1). Det ble observert for første gang i 2005, ved hjelp av forskningsfartøyet Alvin, nær en oppstrømning av svovelholdig varmt vann på $2200 \mathrm{~m}$ dyp sør for Påskeøya. For å fange dyret uskadet ble det brukt en «slurp gun», som er et rør med et vakuumkammer som kan åpnes og lukkes. På forskningsskipets videoskjerm så ikke denne skapningen ut til å være så forskjellig fra de mange albinokrabbene på bunnen, men marinbiologen Michel Segonzac var observant nok til å ane at her hadde vi noe enestående. Sammen med to kolleger plasserte han det innfangede dyret på et sortlakkert bord, og tok et bilde som vakte oppsikt over hele verden. Isolert og belyst på en nattsvart bakgrunn ble denne representanten fra de store havdyp et stykke fascinerende foto-

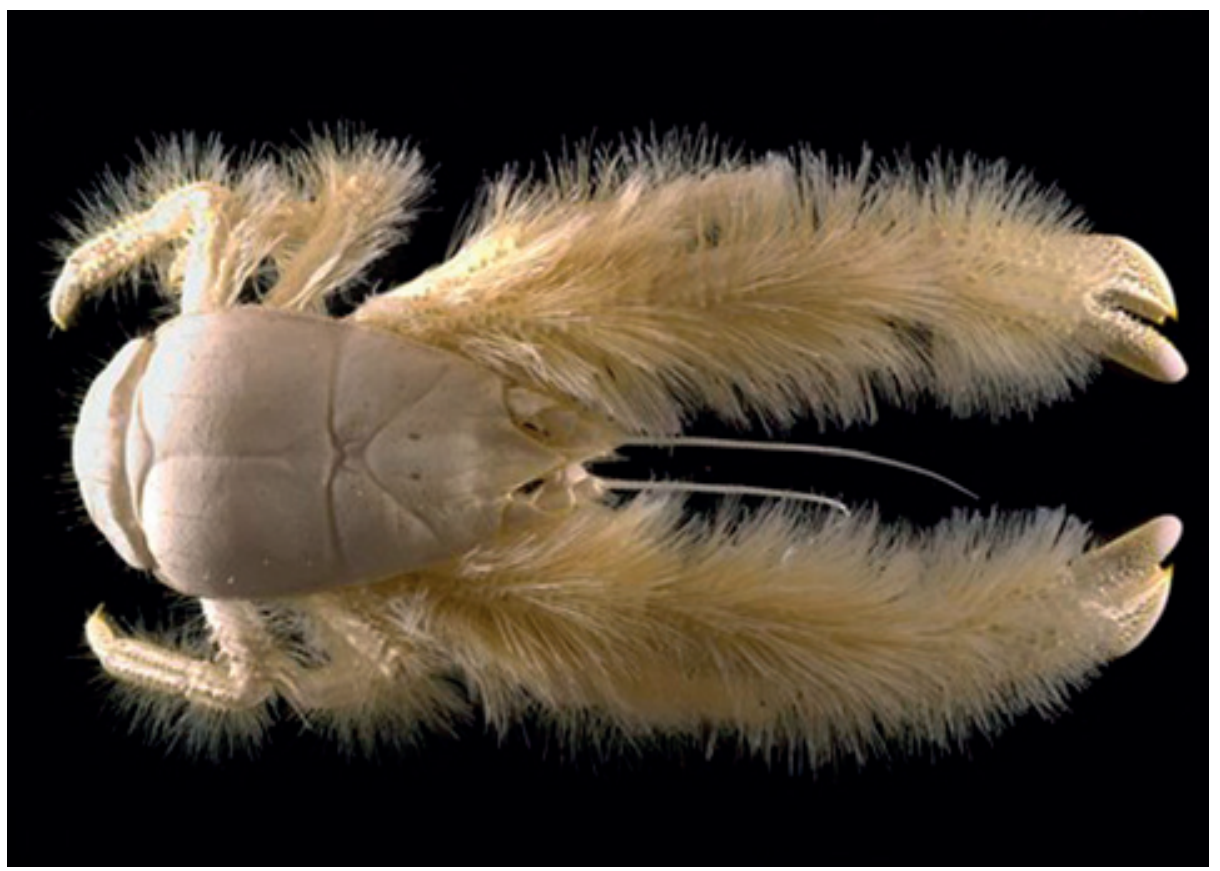

Kiwa hirsuta. Kiwa er skalldyrenes gudinne i den polynesiske mytologien, hirsutus betyr raggete og lodden. Foto @ A. Fifis/AP/SCANPIX kunst. Bildet ble i løpet av kort tid gjengitt i tidsskrifter og aviser over hele verden. På Internett ble det et varig ikon. Det vitenskapelige navn ble Kiwa hirsuta. Et populært navn er yetikrabben. Det skyldes at dyret ble observert gående oppreist på de fire bakre par bein med gripeklørne rettet fremover og oppover. Inntrykket var en mystisk, pelskledd skapning på vandring, omtrent slik mange har forestilt seg den kryptiske avskyelige snømann i Himalaya. Hårene som kalles cetae, er tilholdssted for lange segmenterte bakterier som tar opp svovelholdige substanser. Det kan være en nyttig symbiose mellom disse kjemotrope mikrobene og Kiwa hirsuta (2). Det som er giftig for et skalldyr, kan være næring for andre.

Hvorfor ble dette bildet så høyt verdsatt? Mange andre av de nyoppdagede dyphavsdyrene er mer spektakulære, det vil si mer fremmedartede. Vi forbinder dem ikke direkte med dyr som vi kjenner fra før. De assosieres snarere med science fiction. Kiwa hirsuta er nok også annerledes, men samtidig ikke helt ukjent. Det kan være denne kombinasjonen av noe kjent og noe ukjent $i$ den levende natur som appellerer så sterkt til oss. Bildet bringer i likhet med de fleste kunstverker frem tanker og overveielser hos betrakteren. Ryggskallet har en uvanlig utforming med ornamentering. Det er en kraftig og stor, konkav brystplate som ikke finnes hos hummer. En detaljert beskrivelse av anatomi og systematikk er publisert (1).

\section{Anton Hauge}

anton.hauge@medisin.uio.no

Avdeling for fysiologi

Institutt for medisinske basalfag

Universitetet i Oslo

Postboks 1103 Blindern

0317 Oslo

Oppgitte interessekonflikter: Ingen

\section{Litteratur}

Macpherson E, Jones W, Segonzac M. A new squat lobster family of Galatheoidea from the hydrothermal vents of the Pacific-Antarctic Ridge. Zoosystema 2005; 27: 709-23.

2. Goffredi SK, Jones WJ, Erlich $\mathrm{H}$ et al. Epibiotic bacteria associated with the recently discovered Yeti Crab, Kiwa hirsuta. Environ Microbiol 2008; 10 $2623-34$

Manuskriptet ble mottatt 12.8. 2009 og godkjent 15.10. 2009. Medisinsk redaktør Anne Gitte Hertzberg. 